\section{Effect of Using Nano and MicroAirborne Abrasive Particles on Bond Strength of Implant Abutment to Prosthesis}

\author{
Mansour Rismanchian¹, Amin Davoudi², Elham Shadmehr ${ }^{3}$
}

Connecting prostheses to the implant abutments has become a concern and achieving a satisfactory retention has been focused in cement-retention prostheses recently. Sandblasting is a method to make a roughened surface for providing more retention. The aim of this study was to compare effects of nano and micro airborne abrasive particles (ABAP) in roughening surface of implant abutments and further retention of cemented copings. Thirty Xive abutments and analogues (4.5 D GH1) were mounted vertically in self-cured acrylic blocks. Full metal $\mathrm{Ni}-\mathrm{Cr}$ copings with a loop on the top were fabricated with appropriate marginal adaptation for each abutment. All samples were divided into 3 groups: first group (MPS) was sandblasted with $50 \mu \mathrm{m} \mathrm{Al}_{2} \mathrm{O}_{3}$ micro ABAP, second group (NSP) was sandblasted with $80 \mathrm{~nm} \mathrm{Al}_{2} \mathrm{O}_{3}$ nano $\mathrm{ABAP}$, and the third group (C) was assumed as control. The samples were cemented with provisional cement (Temp Bond) and tensile bond strength of cemented copings was evaluated by a universal testing machine after thermic cycling. The t test for independent samples was used for statistical analysis by SPSS software (version 15) at the significant level of 0.05 . Final result showed significant difference among all groups $(p<0.001)$ and MPS manifested the highest mean retention $(207.88 \pm 45.61 \mathrm{~N})$ with significant difference among other groups $(p<0.001)$. The control group showed the lowest bond strength as predicted $(48.95 \pm 10.44 \mathrm{~N})$. Using nano or micro ABAP is an efficient way for increasing bond strengths significantly, but it seems that micro ABAP was more effective.
'Dental Implant Research Center and Department of Prosthodontics, School of Dentistry, lsfahan University of Medical Sciences, Isfahan, Iran ${ }^{2}$ Dental Students Research Center, School of Dentistry, lsfahan University of Medical Sciences, Isfahan, Iran ${ }^{3}$ Torabinejad Research Center and Departments of Endodontics, School of Dentistry, Isfahan University of Medical Sciences, Isfahan, Iran

Correspondence: Amin Davoudi, Dental Implant Research Center of Isfahan University of Medical Sciences, Hezarjarib St, lsfahan, Iran. Tel: +98-9132949318. e-mail: amindvi@yahoo.com

Key Words: implant abutments, sandblasting, surface treatment, temporary cement.

\section{Introduction}

As implant technology has been introduced, prosthodontics' science has been evolved. The use of implant-supported prostheses instead of missing tooth has gained acceptance among people all over the world $(1,2)$.

One of the main concerns is the method of connecting prostheses to the implant abutments. With respect to all methods, two types of connection have been introduced: (A) Cement-retained and (B) Screw-retained prostheses $(1,3,4)$. Cement-retained prostheses have the benefits of more passive superstructure, lower costs of laboratory procedures and optimal aesthetics in anterior region. Passive fitness is the most remarkable benefit of cementretained restoration which declines the possibility rates of screw loosening, fractures and optimal occlusion due to lack of screw hole (2,3-5). In spite of the advantages, some disadvantages cannot be overlooked: the retrivability limitation when removing of crown is required; and more possibility of inflammation due to the remnant cement (4-6). However, both types have their aficionados and there is not any precise document about the superiority of each one $(4,7)$.

Implant abutments need more consideration for enhancing higher retention during fabrication due to their limitations in diameter and tapering than natural teeth (8). The following factors influence the retention of implant prostheses: geometry of abutment preparation, abutment taper, surface area, abutment's height, surface roughness, and luting agent $(1,2,9)$. Surface roughness and luting agents are more controllable clinically (2). As implants would not manifest signs of occlusal discrepancies in the first period of occlusal loadings, clinicians select provisional luting agents to maintain retrievability, evaluating oral hygiene and soft tissue response in follow ups (8). However, a loose restoration would not be acceptable, especially in anterior (5) and posterior regions with short abutments (heights of 3-4 mm). Therefore, sufficient retention for provisional luting is needed to retain the prostheses during function (6).

Most dental implants and abutments are usually manufactured from commercially pure titanium because of its biocompatibility and excellent mechanical properties (1). Using micro-sized particles, for making roughened abutment's surface, causes micro retentive ridge and groove patterns and results in more retention $(10,11)$. Some methods are suggested to treat surfaces like: sandblasting, acid-etching, grit blasting and etc. Sandblasting with airborne abrasive particles (ABAP) is the most common method for treating abutment surface $(12,13)$. Sahu et al. (9) investigated the effect of abutment surface modification on the further retention of restorations, which were cemented with polymer based cement. They declared that sandblasting 
was an effective method to increase the retentive strength. In another study, Kurt et al. (14) examined the effect of different surface treating methods on retention of single crowns. They tried $\mathrm{CO}_{2}$ laser etching, ABAP sandblasting, titanium nitride coating and silicoating. Their final results showed the highest retention in sandblasted group. Wiskott et al. (15) claimed that sandblasting doubled the resistance to dynamic lateral loading. In another study, Al Hamad et al. (16) stated that sandblasting abutments with micro-sized ABAP significantly increased bonding strength in samples. There are varieties of ABAP which are used in sandblasting but the most commons are $\mathrm{Al}_{2} \mathrm{O}_{3}$ and $\mathrm{TiO}_{2}$.

Nanotechnology has emerged in many branches of science such as medicine, chemistry and physics. It includes designs and fabrication of materials, devices and systems at nanometer (1-100 nm) dimensions. Therefore, materials are classified based on the structure as nanostructure, nano crystal, nano coatings, nano fibers and nano particles (17). Recently some studies focused on the use of nanoparticles for treating implant surfaces especially for higher osseointegration and survival rates (18).

Due to the importance of retention in implantsupported prostheses especially cement-retained ones, the purpose of this study was to compare nano and micro ABAP sandblasting and their effects on retention of cemented copings to implant abutments. The null hypothesis is that using nano ABAP might provide higher prepared higher surfaces for bonding to the cements

\section{Material and Methods}

In this observational-analytical study, 30 Xive implant screwed abutments with their exclusive analogues (4.5D GH1) (XiVE, Dentsply, Friadent GmbH, Mannheim, Germany) were used as the samples of this observation. All 30 analogues were mounted vertically in self-cured acryl (Meliodent, Heraeus Kulzer, Hanau, Germany) by a surveyor (Ney Surveyor, Dentsply, York, PA, USA) 2 mm above the

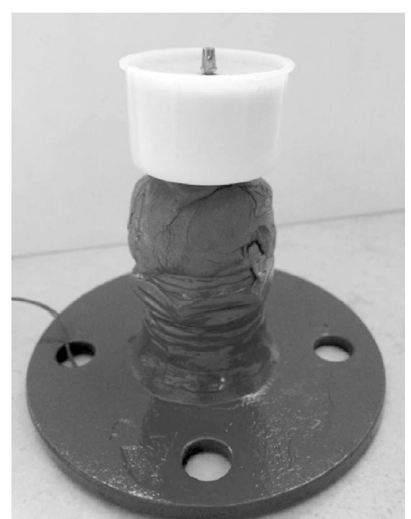

Figure 1. Designed gyrator for making roughened surface equally. margins. The titanium abutments were attached to each implant analogue and torqued to $35 \mathrm{~N} . \mathrm{cm}$.

Thirty copings were made by prefabricated burn-out caps with a loop on the occlusal surface of each coping for retention test. The patterns were invested in a phosphatebonded investment (Ceravest Quick, GC, Tokyo, Japan) and casted in Ni-Cr alloy (Rexillium III, Pentron, Wallingford, CT, USA). Ultrasonic cleaner and hydrofluoric acid were used for divesting and cleaning the copings. The inner surfaces of the copings were observed under $4 \times$ magnification for detecting any irregularities. Silicon disclosing medium (Fit Checker, GC Co, Tokyo, Japan) was used for insurances of marginal fitness. A gyrator was designed by using a gearbox motor with a place for mounting samples, which turned around twice in $1 \mathrm{~min}$ in order to make sure that all the surfaces of the abutment were roughened equally (Fig. 1).

All samples were divided into 3 groups with 10 abutments in each of them. In the first group (named MPS), all samples were sandblasted with $50 \mu m \mathrm{Al}_{2} \mathrm{O}_{3}$ micro ABAP (Edelkorund, Ernst Hinrichs GmbH, D-38644, Golsar, Germany) and the second group (named NPS) was sandblasted with $80 \mathrm{~nm} \mathrm{Al} \mathrm{O}_{3}$ nano ABAP (US Research Nanomaterials, Inc.). The third group (named $\mathrm{C}$ ) was assumed as the control group.

The sandblasting procedure was prepared by a sandblasting machine (Pieme, S.R.L, Lonigo, Vicenza, Italy) with $3.5 \mathrm{KPa}$ from a $5 \mathrm{~mm}$ distance for $1 \mathrm{~min}$ (1). Only the titanium abutments were sandblasted in order to evaluate the effects of ABAP on roughening the abutments and bonding of cement to titanium (Fig. 2).

All copings were cemented to the abutments by Temp Bond cement (Kerr, Salerno, Italy) with $5 \mathrm{~N}$ forces for 10 min according to manufacturer instruction, respectively. All samples (meaning coping-abutment-analogue) were subjected to 5,000 thermal cycles between $5^{\circ}$ and $55^{\circ}$ in a themal cycler (Delta Tpo2, Nemo, Mashhad, Iran).

Tensile bond strength of cemented copings was evaluated by a universal testing machine (21046, Walter+bai, Switzerland) with crosshead speed of $5 \mathrm{~mm} /$

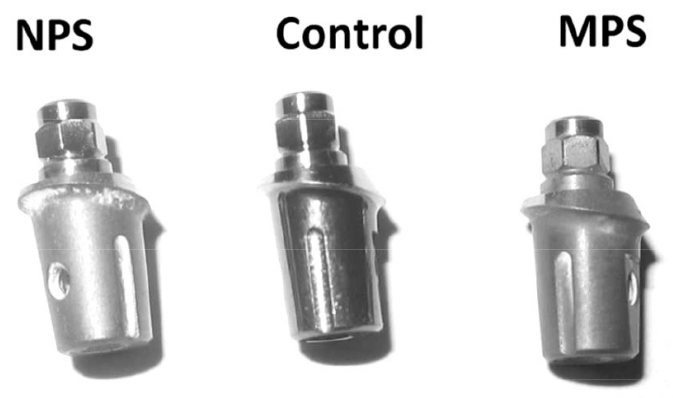

Figure 2. Macro view of sandblasted abutments of each group. 
$\min$ and $500 \mathrm{~kg}$ force. The force was applied until observing the dislodgment of coping and failure of cementation.

Two walls of acrylic bases were trimmed slightly parallel to each other in order to become appropriate for observing whole surface of abutment under microscope completely. Therefore, the samples were embedded on two parallel sides of the bases and cement remnants were observed under stereomicroscope (Motic SMZ-168 Stereo Zoom Microscope, Ted Pella Inc., CA, USA) under 20x magnification. Two images were taken from each abutment and full coverage was achieved. The percentage of cement remnants was evaluated with Photoshop Software version 8 (Adobe Systems, San Jose, CA, USA).

Finally, analysis with a scanning electron microscope (Vega II Tescan, Tescan Orsay Holding, Kohoutovice Czech Republic) was proceeded to characterize the sandblasted surface of abutments and comparing the roughness which was caused by two types of nano and micro ABAP. In order to preparing samples for SEM analysis, the following stages were done: fixation, post fixation, washing, dehydration, decication, and gold coating (Edwards Ltd., London, UK).

The mean of tensile bond strength necessary to dislodge the copings from the abutments, were recorded and all data were analyzed by the t-test for independent samples using SPSS software version 15 (SPSS Inc., Chicago, IL, USA) at a significant level of 0.05 .

\section{Results}

As the analysis variances were not homogeneous among the groups, the Kruskal Wallis test was done and significant difference in results was achieved $(p<0.001)$. Then $t$-test for independent samples was administered to analyze the recorded data and the final results showed significant difference among all groups $(p<0.001)$.

Table 1 demonstrates the mean values and standard deviations of tensile bond strengths, which were recorded from all groups. MPS showed the highest mean values of retention $(207.88 \pm 45.61 \mathrm{~N})$ with significant difference among other groups $(p<0.001)$.

The NPS group $(136.97 \pm 31.09 \mathrm{~N})$ showed the higher retention value than group $\mathrm{C}(48.95 \pm 10.44 \mathrm{~N})$ with significant difference $(p<0.001)$. The control group showed

Table 1. Mean values and standard deviations of retentive values (N) which were obtained from tensile test in all the groups

\begin{tabular}{lccc}
\hline Groups & $\begin{array}{c}\text { Mean retention } \\
\text { value }\end{array}$ & $\begin{array}{c}\text { Minimum } \\
\text { retention value }\end{array}$ & $\begin{array}{c}\text { Maximum } \\
\text { retention value }\end{array}$ \\
\hline C & $48.95 \pm 10.44$ & 32.78 & 63.09 \\
MPS & $207.88 \pm 45.61$ & 146.72 & 275.73 \\
NPS & $136.97 \pm 31.09$ & 68.26 & 192.49 \\
\hline
\end{tabular}

the lowest retention value as predicted $(48.95 \pm 10.44 \mathrm{~N})$.

Table 2 presents the distribution of cement remnants on the abutments after dislodgment. The largest number of samples with $\geq 60 \%$ cement remnants were observed in the MPS group $(n=4)$, while the lowest number of samples were observed in group $C(n=0)$.

Figures 3 and 4 represent the SEM analysis of the abutment's surfaces that were roughened with $50 \mu \mathrm{m}$ (Fig. 3) and $80 \mathrm{~nm}$ (Fig. 4) $\mathrm{ABAP}$, respectively. $\mathrm{Al}_{2} \mathrm{O}_{3}$ particles became encrusted on the titanium surface because of the velocity and pressure and hit the surface, which made a mechanical bonding to the cements.

The $80 \mathrm{~nm} \mathrm{Al}_{2} \mathrm{O}_{3} \mathrm{ABAP}$ made very small interface, but $50 \mu \mathrm{m} \mathrm{Al} \mathrm{O}_{3} \mathrm{ABAP}$, which is mostly regular, appeared to make larger microstructure irregularities.

\section{Discussion}

There have been many studies about the effect of surface treatment on retention strengths of cemented prostheses to the abutments $(4,5,9,11,14)$. However, few studies evaluated the effect of nano scale surface treating on retentive strength. Hence, the impact of nano and micro ABAP on retentive strength was investigated in cemented coping to implant abutments in this study. Factors that influence the amount of retention seems to have paramount role in cemented implant-supported restorations, including: taper or parallelism, surface area and height, surface finish or roughness and type of cement $(2,9,14)$.

First of all, the results of present study confirmed that making roughened surface results in higher values of retentive strength as reported elsewhere $(2,9,14,15,19,20)$.

Results of present study showed that the highest mean retentive strength were caused by $50 \mu \mathrm{m}$ micro ABAP $(207.88 \pm 45.61 \mathrm{~N})$ with significant difference in comparison with the other groups $(p<0.001)$. Also, the highest number of samples with $\geq 60 \%$ of remnant cements in MPS group might admit the fact that deeper and larger irregularities resulted in lesser detached cements. These findings reflect that micro ABAP created more retentive surface than nano $A B A P$, statistically. Larger with deeper projections and grooves made by micro ABAP, which were filled with cements, might cause more retention. The present results

Table 2. Distributions of cement remnant on the abutments of all groups

\begin{tabular}{lccc}
\hline Groups & $\begin{array}{c}<30 \% \text { remnant } \\
\text { cement }\end{array}$ & $\begin{array}{r}30-60 \% \text { remnant } \\
\text { cement }\end{array}$ & $\begin{array}{c}\geq 60 \% \text { remnant } \\
\text { cement }\end{array}$ \\
\hline C & 7 & 3 & 0 \\
MPS & 2 & 4 & 4 \\
NPS & 4 & 4 & 2 \\
\hline
\end{tabular}


are in accordance with those of a previous study in which $250 \mu \mathrm{m}$ and $50 \mu \mathrm{m}$ micro ABAP sandblasting were compared and higher retention values were caused by larger size of micro ABAP (4).

In another aspect, providing nano scale roughness hypothesizes more prepared surface roughness areas and might lead to higher retention values reasonably. However, the type of cement is another factor which affects the retention strength. Schmage et al. (21) stated that thin and homogeneous film thickness of cement has a paramount impact in providing passive fitness and impressively increases the retentive strength. These results are consistent with those of Wiskott et al. (15). Most probably, higher tensile bond strength values would be obtained when the cement flows into irregularities and then sets, which ends in higher inter-lockage (20). As mentioned before, many clinicians try to use provisional luting agents to maintain retrievability and evaluating occlusal discrepancies, oral hygiene and soft tissue response in follow ups (8). Temp Bond was used as a provisional cement in present study. The eugenol-containing luting agents can inhibit the growth of bacteria and further inflammations. Because of their lower cost and ease of handling many clinicians tend to use them as temporary materials (22).

According to Kim et al. (2), the method of treating surface depends on the provisional luting agent; and bond strength has liner correlation with wettability of the cement. The more the surface is getting wet with cement material, the more retention is gained (1). Temp Bond has low wettability and it might be the reason why NPS group showed lower retention values than the MPS group.

Sahu et al. (9) found that the mean retentive value

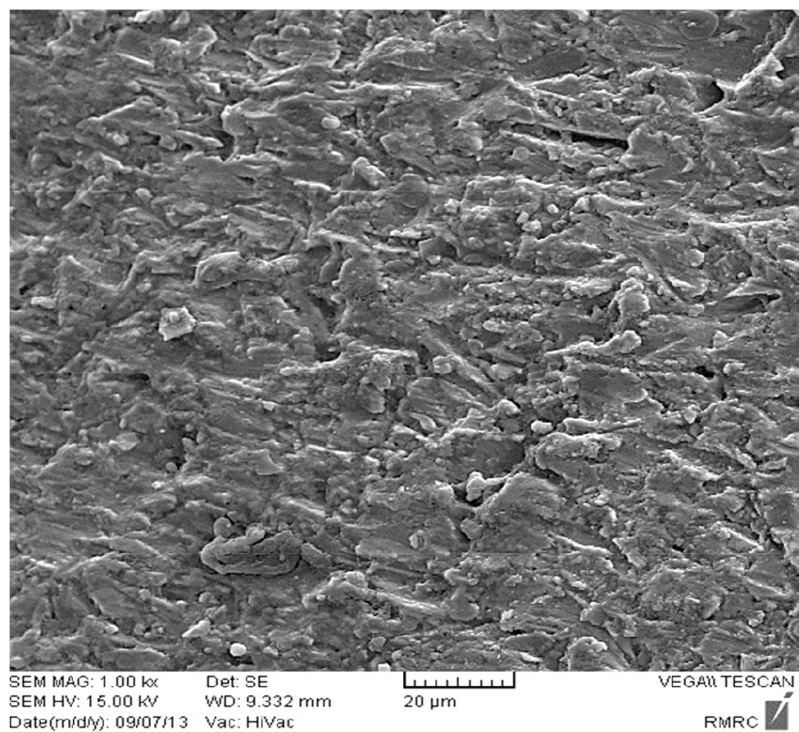

Figure 3. SEM image of abutment's surface sandblasted with $50 \mu \mathrm{m}$ $\mathrm{Al}_{2} \mathrm{O}_{3}$ (1000x magnification). was $743.8 \pm 62.4 \mathrm{~N}$ for micro ABAP sandblasted group with considering that polymeric implant cement was used for cementation. Additionally, sandblasting was administered for both copings and abutments with $110 \mu \mathrm{m}$. In present study, only the abutments were sandblasted in order to evaluate effects of ABAP on bonding of cement to titanium abutments not copings; and the size of ABAP was smaller (50 $\mu \mathrm{m})$.

In another study, the mean retention values were recorded $506.02 \pm 18.04 \mathrm{~N}$ for micro ABAP group (14). The difference between two mentioned studies might be due to different types of cements and size of ABAP.

Kim et al. observed the effect of surface treating and different luting agents on retentive strengths. They used $50 \mu \mathrm{m}$ ABAP with different luting agent, especially Temp Bond. They concluded that the tensile strength of Temp Bond was the lowest and sandblasting might be an effective method to increase retention of a provisional acrylic crown when Temp Bond NE (non-eugenol) was used (2).

The other factor, which affect the retentive strengths, is the height of abutments (23-25); meaning that higher abutments made higher values of retention. Saleh Saber et al. (6) evaluated the retention of cemented coping to abutments with $2 \mathrm{~mm}$ height without any prior surface preparation in one of their groups. Their result is comparable with the control group of present study. The mean retention was $9.92 \pm 4.11 \mathrm{~N}$ in that study; however the recorded retention was $48.95 \pm 10.44$ in present study for the control group. The luting agent was the same, so deference magnifies the importance of abutments heights.

Depending on compared results, using other cements with higher wettability is suggested to evaluate the

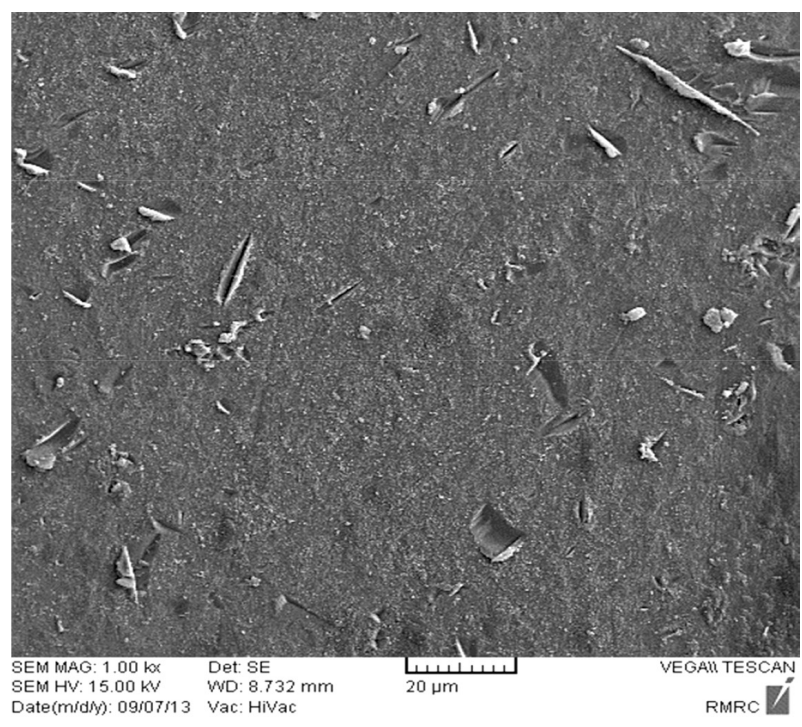

Figure 4. SEM image of abutment's surface sandblasted with $80 \mathrm{~nm}$ $\mathrm{Al}_{2} \mathrm{O}_{3}$ (1000x magnification). 
capability of nano ABAP sandblasting technique more genuinely. Also, it is recommended to investigate other types of cements and implants with different heights; trying other treating methods with different size of particles; and roughening both crown and implant abutments to find more practical results in future studies.

Within the limitations of this study, it may be concluded that sandblasting with ABAP (nano or micro) is effective to make higher bond strengths. However, it seems that using micro ABAP is more efficient due to the fact that nano ABAP reduced the wettability of Temp Bond provisional cement.

\section{Resumo}

A conexão das próteses nos pilares dos implantes dentários é um fator de preocupação e a obtenção de uma retenção satisfatória tem sido objeto de estudos recentes em próteses com retenção cementária. 0 jateamento é um método de obter uma superfície áspera para aumentar a retenção. 0 objetivo do presente estudo foi comparar os efeitos de jateamento com nano- e micropartículas abrasivas para tornar áspera a superficie dos pilares de implantes e a consequente aumentar a retenção dos copings cimentados. Trinta pilares Xive com seus análogos (4.5 D GH1) foram montados na posição vertical em blocos de acrílico auto-polimerizados. Copings metálicos de $\mathrm{Ni}$ $\mathrm{Cr}$ com uma alça no topo foram feitos com adaptação marginal apropriada para cada pilar. Todas as amostras foram divididas em três grupos: $01^{\circ} \mathrm{grupo}$ (MPS) foi jateado com micropartículas de $\mathrm{Al}_{2} \mathrm{O}_{3}$ com $50 \mu \mathrm{m}$ de tamanho - médio; $02^{\circ}$ grupo (NPS) foi jateado com nanopartículas de $\mathrm{Al}_{2} \mathrm{O}_{3}$ com $80 \mathrm{~nm}$ de tamanho médio; e o $3^{\circ}$ grupo (C) foi considerado controle. As amostras foram cimentadas com cimento provisório (Temp Bond) e a resistência à tração dos copings cimentados foi avaliada em máquina universal de ensaios após processo de termociclagem. 0 teste $t$ para amostras independentes foi usado para fins de análise estatística empregando-se o software SPSS v. 15, com nivel de significância de 0,05 . Os resultados demonstraram diferença significante entre todos os grupos $(p<0,001)$ e o grupo MPS mostrou 0 maior valor médio de resistência de união $(207,88 \pm 45,61 \mathrm{~N})$ com diferenças significantes em relação aos outros grupos $(p<0,001)$. Conforme previsto, o grupo controle obteve o menor valor de resistência $(48,95 \pm 10,44 \mathrm{~N}) .0$ jateamento com micro ou nano partículas mostrou-se um modo eficaz de aumentar significativamente a resistência de união, mas aparentemente as micropartículas são mais eficazes.

\section{Acknowledgements}

This article was based on the thesis with ID number of 291297. Also, we would like to express our gratitude to Torabinejad Research Center and Dental Implant Research Center of Isfahan University of Medical School for helping us to convey our study.

\section{References}

1. Yoshida $T$, Terashima $N$, Niiro $T$, Nagasawa $S$, Ito $M$, Yagasaki $H_{\text {, et al.. }}$ Bond strength of resin cements to $\mathrm{H}_{2} \mathrm{O}_{2}$-treated titanium plates. Dent Mater 2005;21:1087-1097.

2. Kim Y, Yamashita J, Shotwell JL, Chong KH, Wang HL. The comparison of provisional luting agents and abutment surface roughness on the retention of provisional implant-supported crowns. J Prosthet Dent 2006;95:450-455.

3. Barbosa GA, das Neves FD, de Mattos M da G, Rodrigues RC, Ribeiro RF. Implant/abutment vertical misfit of one-piece cast frameworks made with different materials. Braz Dent J 2010;21:515-519.

4. Lee HY, Lee HS. In vitro study of the tensile bond strength of cement-retained single implant prosthesis by the various provisional luting cements and the surface treatment of abutments. J Kor Acad Prosthodont 2002;40:296-305.
5. Kokubo $Y$, Kano $T$, Tsumita $M$, Sakurai $S$, Itayama A, Fukushima S. Retention of zirconia copings on zirconia implant abutments cemented with provisional luting agents. J Oral Rehabil 2010;37:48-53.

6. Saleh Saber F1, Abolfazli N, Nuroloyuni S, Khodabakhsh S, Bahrami $M$, Nahidi $R$, et al.. Effect of abutment height on retention of single cement-retained, wide- and narrow-platform implant-supported restorations. J Dent Res Dent Clin Dent Prospects 2012;6:98-102.

7. Pan $\mathrm{YH}$, Lin CK. The effect of luting agents on the retention of dental implant-supported crowns. Chang Gung Med J 2005;28:403-410.

8. Carl E. Misch. Dental implant prosthetics. 1st ed. Elsevier. Mosby. 2005.

9. Sahu N, Lakshmi N, Azhagarasan NS, Agnihotri Y, Rajan M, Hariharan R. Comparison of the effect of implant abutment surface modifications on retention of implant-supported restoration with a polymer based cement. J Clin Diagn Res 2014;8:239-242.

10. Youn YA, Lee YK, Lee DY, Kim NY, Lim YK. Effect of surface treatment and type of cement on the retentive strength of orthodontic bands on gold alloy crowns. Am J Orthod Dentofacial Orthop 2007;132:728 e1-e6.

11. Blue DS, Griggs JA, Woody RD, Miller BH. Effects of bur abrasive particle size and abutment composition on preparation of ceramic implant abutments. J Prosthet Dent 2003;90:247-254.

12. Fischer J, Grohmann P, Stawarczyk B. Effect of zirconia surface treatments on the shear strength of zirconia/veneering ceramic composites. Dent Mater J 2008;27:448-454.

13. Thompson JY, Stoner BR, Piascik JR, Smith R. Adhesion/cementation to zirconia and other non-silicate ceramics: where are we now?. Dent Mate 2011;27:71-82.

14. Kurt M, Kulunk T, Ural C, Kulunk S, Danisman S, Savas S. The effect of different surface treatments on cement-retained implant-supported restorations. J Oral Implantol 2013;39:44-51.

15. Wiskott HW, Belser UC, Scherrer SS. The effect of film thickness and surface texture on the resistance of cemented extracoronal restorations to lateral fatigue loading. Int J Prosthodont 1999;12:255-62.

16. Al Hamad KQ, Al Rashdan BA, Abu-Sitta EH. The effects of height and surface roughness of abutments and the type of cement on bond strength of cement-retained implant restorations. Clin Oral Implants Res 2011;22:638-644.

17. Mantri SS, Mantri SP. The nano era in dentistry. J Nat Sci Biol Med 2013;4:39-44.

18. Bueno $R$ de $B$, Adachi $P$, Castro-Raucci LM, Rosa AL, Nanci $A$, Oliveira PT. Oxidative nanopatterning of titanium surfaces promotes production and extracellular accumulation of osteopontin. Braz Dent J 2011;22:179-184.

19. Campos TN, Adachi LK, Miashiro K, Yoshida H, Shinkai RS, Neto PT, et al.. Effect of surface topography of implant abutments on retention of cemented single-tooth crowns. Int J Periodontics Restorative Dent 2010;30:409-413.

20. Shahin R, Kern M. Effect of air-abrasion on the retention of zirconia ceramic crowns luted with different cements before and after artificial aging. Dent Mater 2010;26:922-928.

21. Schmage $P$, Sohn J, Ozcan M, Nergiz I. Effect of surface treatment of titanium posts on the tensile bond strength. Dent Mater 2006;22:189194.

22. Ramp MH, Dixon DL, Ramp LC, Breeding LC, Barber LL. Tensile bond strengths of provisional luting agents used with an implant system. J Prosthet Dent 1999;81:510-514.

23. Abbo B, Razzoog ME, Vivas J, Sierraalta M. Resistance to dislodgement of zirconia copings cemented onto titanium abutments of different heights. J Prosthet Dent 2008;99:25-29.

24. Cano-Batalla J, Soliva-Garriga J, Campillo-Funollet M, Munoz-Viveros CA, Giner-Tarrida L. Influence of abutment height and surface roughness on in vitro retention of three luting agents. Int J Oral Maxillofac Implants 2012;27:36-41

25. Emms M, Tredwin CJ, Setchell DJ, Moles DR. The effects of abutment wall height, platform size, and screw access channel filling method on resistance to dislodgement of cement-retained, implant-supported restorations. J Prosthodont. 2007;16:3-9.

Received July 23, 2014 Accepted December 1, 2014 